\title{
Is Hernia in fact a world journal?
}

\author{
R. C. Read
}

Received: 10 November 2011 / Accepted: 9 August 2012/Published online: 23 August 2012

(C) Springer-Verlag 2012

The first issue of Hernia was published in May of 1997 by Springer-Verlag as the official publication of the European Research Group on the Abdominal Wall (GREPA) and the American Hernia Society (AHS). The Editor-in-Chief was J. P. Chevrel of Paris, France who initiated this action [1]. It was dedicated to the study of herniation affecting the abdomen, the most common indication for operations performed by general surgeons at that time. These procedures were often delegated to junior staff so that their seniors could concentrate their efforts on what was then considered to be more challenging, surgery of the digestive tract or cardiovascular system. Chevrel, with a small group of French surgeons, had founded GREPA in 1979, 17 years before the AHS was formed under the leadership of Arthur Gilbert of Miami supported by a dozen other herniologists in the United States. From the inception of Hernia, the statement "The World Journal of Hernia and Abdominal Wall Surgery" has been placed on the front cover of each issue.

At an editorial meeting regarding Hernia held on June 20, 2003, performance and achievements were documented. Considerably more manuscripts related to the topic of hernia were being published in Hernia compared with the Annals of Surgery, Archives of Surgery, the American Journal of Surgery, and the British Journal of Surgery. Participating countries had increased from 9 in 1997 to 18 in 2002. Articles and reviews dominated, and case reports had climbed from 2 in 1997 to 12 in 2002. Continents involved were Europe, America, Asia, Australia, and Africa. The number of manuscripts published had doubled between 2001 and 2003.

R. C. Read ( $\square)$

304 Potomac Street, Rockville, MD 20850, USA

e-mail: read@post.harvard.edu
In his June 2007 editorial at the tenth anniversary of Hernia, Schumpelick [2] quoted Nyhus [3] whose 1997 editorial was the first contribution to be published in the initial issue of Hernia. "We are indebted to Professor J. P. Chevrel and his colleagues in the Group for Study and Research of the Abdominal Wall (GREPA) of France for taking the initiative to produce a surgical journal dedicated to the study of hernia. The need for continuing study of this scourge of mankind is apparent when we remind ourselves that over 800,000 operations for the 'cure' of hernia are performed in the world each year." Schumpelick then quoted Chevrel [1] who stressed that "Numerous problems are still without solutions today: the choice of an international classification acceptable to all, research into better prostheses, better refinement of the indications for traditional surgery from Bassini to Schouldice and of laparoscopic surgery." Schumpelick [2] enumerated a total of 677 original contributions from 25 countries having been published in the journal Hernia since its inception.

In the next issue of Hernia (August 2007), Alexandre reported on the death of Jean-Paul Chevrel (1933-2006). The obituary [4] recounted his surgical education and the many skills he developed. He had formed a number of societies and belonged to others. He had published over 400 papers in French or international journals. He remained Editor-in-Chief of Hernia until 2001. His extensive travels around the world were made to present at conferences or meet with his counterparts abroad demonstrating intellectual precision. All of this was accomplished despite suffering from a painful implacable disease for 6 years.

Table 1 presents information regarding 1,221 original contributions (OCs) with first authors from 41 countries, which were published in 69 consecutive issues of Hernia from May 1997 until June 2011. The number of OCs increased from 42 in 1997 and 1998 to 134 in 2010 and 65 
Table 1 Published original contributions May 1997-June 2011

\begin{tabular}{|c|c|c|c|c|c|c|c|}
\hline \multirow[t]{2}{*}{ Years } & \multicolumn{6}{|c|}{ Geographical region of origin } & \multirow{2}{*}{$\begin{array}{l}\text { Total number of } \\
\text { original contribution }\end{array}$} \\
\hline & Europe $^{\mathrm{a}}$ & $\begin{array}{l}\text { North } \\
\text { America }^{b}\end{array}$ & $\begin{array}{l}\text { Asia and } \\
\text { Australia }^{c}\end{array}$ & $\begin{array}{l}\text { Central and } \\
\text { South America }^{\mathrm{d}}\end{array}$ & $\begin{array}{l}\text { Middle } \\
\text { East }^{\mathrm{e}}\end{array}$ & Africa $^{f}$ & \\
\hline 1997 & 29 & 13 & 0 & 0 & 0 & 0 & 42 \\
\hline 1998 & 23 & 18 & 0 & 1 & 0 & 0 & 42 \\
\hline 1999 & 32 & 12 & 3 & 1 & 0 & 0 & 48 \\
\hline 2000 & 49 & 13 & 1 & 3 & 2 & 0 & 68 \\
\hline 2001 & 31 & 12 & 1 & 5 & 0 & 1 & 50 \\
\hline 2002 & 26 & 15 & 2 & 2 & 3 & 0 & 48 \\
\hline 2003 & 39 & 14 & 2 & 3 & 3 & 0 & 61 \\
\hline 2004 & 69 & 34 & 4 & 5 & 3 & 1 & 116 \\
\hline 2005 & 64 & 24 & 5 & 1 & 2 & 1 & 97 \\
\hline 2006 & 54 & 31 & 9 & 4 & 3 & 0 & 101 \\
\hline 2007 & 72 & 19 & 10 & 2 & 3 & 3 & 109 \\
\hline 2008 & 76 & 36 & 13 & 4 & 2 & 2 & 133 \\
\hline 2009 & 54 & 25 & 17 & 1 & 2 & 8 & 107 \\
\hline 2010 & 82 & 25 & 16 & 4 & 3 & 4 & 134 \\
\hline 2011 & 31 & 23 & 8 & 1 & 1 & 1 & 65 \\
\hline Total & 731 & 314 & 91 & 37 & 27 & 21 & 1,221 \\
\hline
\end{tabular}

${ }^{a}$ Europe: United Kingdom 128, Italy 93, France 90, Germany 84, Turkey 84, Spain 57, the Netherlands 52, Greece 35, Sweden 33, Denmark 27, Belgium 18, Austria 13, Poland 10, Switzerland 7, Finland 6, Croatia 5, Bulgaria 3, Serbia 2, Ireland 2, Lithuania 2, Portugal 1, Hungary 1, Czech Republic 1, Estonia 1

b North America: United States 304, Canada 10

c Asia and Australia: India 52, China 12, Australia 11, Japan 5, South Korea 3, Taiwan 2, Singapore 2, Thailand 2, Brunei 1, Pakistan 1

${ }^{d}$ Central and South America: Mexico 15, Brazil 14, Chile 5, Argentina 3

e Middle East: Israel 14, Iran 7, Saudi Arabia 3, United Arab Emirates 2, Iraq 1

${ }^{\mathrm{f}}$ Africa: Egypt 11, Nigeria 3, Morocco 2, Ghana 2, Cameroon 1, South Africa 1, Tunisia 1

in the first half of 2011. Overall, most OCs came from Europe $(731,59.9 \%)$, with 90 from France and the remainder from 23 other countries. The next largest number of OCs came from the northern American continent (314, $25.7 \%$ ), with 304 from the United States and 10 from Canada. In 1997, OCs originated only from Europe or North America. However, eventually a total of 91 (7.4\%) OCs originated from Asia or Australia from 1997 to 2011(10 countries), with 37 (3.0\%) OCs originating in Central or South America during this time period (four countries), 27 (2.2\%) from the Middle East (five countries), and $21(1.7 \%)$ from Africa (seven countries) (Table 1).

Thus, Chevrel's remarkable vision of the future for herniology has been proven to be correct. He has inspired a new generation of surgeons to concentrate on a subspecialty rather than remain in general surgery. The vision of Hernia as being a world journal is now a fact.

Acknowledgments I would like to thank Rhonda Peavy for her assistance.

\section{References}

1. Chevrel JP (1997) GREPA and hernia. Hernia 1:2

2. Schumpelick V (2007) Editorial for the 10th anniversary of the world journal of hernia and abdominal wall surgery. Hernia 11(3):209

3. Nyhus LM (1997) Editorial. An international comprehensive surgical journal dedicated to the subject of Hernia. Hernia 1:1

4. Alexandre JH (2007) Obituary. Jean-Paul Chevrel (1933-2006). Hernia 11(4):293-296 